\title{
NECROLÓGIO
}

\section{Louis Olivier PhD (1913-1990)}

No dia 16 de novembro de 1990 faleceu o Dr. Louis Olivier, parasitologista dos Estados Unidos. Trabalhou na Organização Mundial de Saúde, na Organização Panamericana da Saúde, no National Institutes of Health e no Serviço de Saúde Pública dos Estados Unidos.
No campo de pesquisa dedicou-se principalmente à esquistossomose, tendo trabalhado durante dois anos em Recife em um estudo de campo sobre caramujos transmissores do Schistosoma mansoni, em companhia de pesquisadores brasileiros. 